\title{
Niger seed (Guizotia abyssinica) alters in vitro rumen fermentation and reduces methane emission
}

\author{
Tariq A. Malik and Madhu Mohini* \\ Animal Nutrition Division, ICAR-National Dairy Research Institute, Karnal 132 001, India
}

Oilseeds can be used to manipulate ruminal fermentation for attaining cleaner and better production. The effect of feed-grade niger seeds was studied on in vitro rumen fermentation parameters in comparison to sunflower seeds. Methane production decreased $(P \leq 0.01)$ with incorporation of both seeds. In vitro digestibility of dry matter and organic matter reduced at higher incorporation levels (above 5\%, DM basis). Fermentation pattern of niger and sunflower seed-based total mixed rations was highly comparable. The relatively higher anti-methanogenic potential of niger seeds could make it a better choice for alleviation of enteric methane and formulation of environment-friendly rations.

Keywords: Digestibility, methane emission, niger and sunflower seeds, rumen fermentation, total mixed rations.

REDUCING the formation of enteric methane $\left(\mathrm{CH}_{4}\right)$ and minimizing the environmental impact of ruminant production is currently an important goal of dairy nutritionists. Being a potent greenhouse gas $(\mathrm{GHG}), \mathrm{CH}_{4}$ is a major concern regarding climate change globally. Enteric $\mathrm{CH}_{4}$ emission from ruminants accounts for about 3.3\% and $17 \%$ of global GHGs and $\mathrm{CH}_{4}$ emissions respective$1 y^{1}$. Moreover, $\mathrm{CH}_{4}$ emission represents up to $15 \%$ loss of gross energy intake in ruminant livestock ${ }^{2}$. In this context, feeding of oilseeds has received much attention as a mechanism to mitigate methane emission from ruminants ${ }^{3}$. However, for obtaining optimum benefits from the supplemental oilseeds; they must not be detrimental to ruminal fermentation and nutrient digestibility. Niger seeds (NS) are a natural source of fat rich in polyunsaturated fatty acids (PUFA), particularly linoleic acid. PUFA are more toxic to ruminal microbes than saturated fatty acids (SFA), and can disturb the function of ruminal microbial cell membranes ${ }^{4,5}$. Additionally, PUFA may act as a sink for hydrogen produced by rumen microbiota on account of bio-hydrogenation ${ }^{6}$. Therefore, incorporation of niger seeds as a lipid source in ruminant rations (as an alternative to conventional lipid sources) may alter

*For correspondence. (e-mail: madhummd@yahoo.co.in) ruminal fermentation and diminish $\mathrm{CH}_{4}$ production effectively.

Indian niger seeds contain about $55 \%$ linoleic acid and $25 \%$ oleic $\mathrm{acid}^{7}$. They are free from toxic constituents and apparently well suited for all classes of livestock that can digest fibrous feeds. However, there is lack of information in the available literature regarding their influence on in vitro as well as in vivo rumen fermentation and methane production. In contrast, sunflower seeds (SS) have been commonly used as a lipid source for formulating energy-dense transition diets and as a means of mitigating methane emissions in ruminants, and hence are broadly described in the literature. They contain over $40 \%$ oil $^{8}$, which consists of a high proportion of linoleic acid $(62-75 \%)^{9}$. These seeds are considered safe, and have high palatability and nutritive value for ruminants. Hence, it seems logical to evaluate the in vitro pattern of niger seeds in comparison to sunflower seeds. Therefore, the present study was undertaken with the objective to evaluate the effect of graded levels $(3 \%, 5 \%, 7 \%$ and $9 \%)$ of niger seeds in total mixed rations (TMRs) on in vitro rumen fermentation, in vitro digestibility and $\mathrm{CH}_{4}$ production in comparison to the similar incremental levels of sunflower seeds.

\section{Materials and methods}

\section{Animals and feeding}

Three rumen cannulated adult male Murrah buffaloes fed on a maintenance ration consisting of wheat straw, available green forage and concentrate mixture were used as rumen liquor donors for in vitro incubations ${ }^{10}$. Animals were individually housed in a well-ventilated stall, having provision for adequate sunlight and amenities for individual feeding. Ad libitum clean and fresh drinking water was made available to the animals thrice daily. Rumen contents were collected from the animals immediately before the morning feeding. All the experimental procedures were put into practice after due approval by the Institutional Animal Ethics Committee. 


\section{TMR preparation and in vitro incubations}

Animal feed-grade samples of niger and sunflower seeds were dried at $65^{\circ} \mathrm{C}$ for $48 \mathrm{~h}$, ground in the laboratory Wiley mill and stored in ziplock bags prior to the preparation of experimental rations. Roughages (maize fodder and wheat straw) and concentrate mixture were mixed to obtain TMRs with $60 \%-40 \%$ portions for forage and concentrate. Ground niger and sunflower seeds, both at incremental levels of $7.5 \%, 12.5 \%, 17.5 \%$ and $22.5 \%$ in the concentrate mixture (corresponding to $3 \%, 5 \%, 7 \%$ and $9 \%$ of total dry matter (DM)) were used to formulate experimental TMRs $(n=8)$. The control TMR (TMRc) was devoid of niger and sunflower seeds, and had the same forage to concentrate ratio $(60: 40)$. TMRs with similar incremental levels of niger and sunflower seeds were balanced for ether extract (EE) and crude protein (CP).

The rumen contents collected in plastic thermos (preheated at $39^{\circ} \mathrm{C}$ ) were immediately transported to the laboratory, where they were flushed continuously with carbon dioxide and strained through four layers of cheese cloth. Prior to incubation, $100 \mathrm{ml}$ calibrated glass syringes (Fortuna Optima, Germany) were placed in an incubator $\left(39^{\circ} \mathrm{C} \pm 1\right)$ for $72 \mathrm{~h}$. About $200 \mathrm{mg}$ sample of each air-equilibrated TMR was incubated with $30 \mathrm{ml}$ of buffered rumen inoculum in the glass syringes for $24 \mathrm{~h}$. Incubation runs were performed thrice in triplicates.

\section{In vitro methane and digestibility determination}

In vitro gas production technique was used for the evaluation of different TMRs ${ }^{11}$. After $24 \mathrm{~h}$, total gas production was measured and representative gas samples $(10 \mathrm{ml})$ were collected from the headspace of the glass syringes in airtight syringes for $\mathrm{CH}_{4}$ analysis. These gas samples were injected into the gas chromatograph (Nucon 5700, India) fitted with stainless-steel column and flame ionization detector (FID). The temperature of the injector, column and detector was $40^{\circ} \mathrm{C}, 50^{\circ} \mathrm{C}$ and $100^{\circ} \mathrm{C}$ respectively.

Pistons of syringes were removed and $\mathrm{pH}$ was measured immediately using a $\mathrm{pH}$ meter. Thereafter, the contents of each glass syringe were centrifuged at $3000 \mathrm{rpm}$ for $15 \mathrm{~min}$ to separate the supernatant (used for $\mathrm{NH}_{3}-\mathrm{N}$ and VFA estimation). Pellets obtained after centrifugation were refluxed with neutral detergent solution, filtered through sintered glass (G-1) crucibles, and the residues were dried in a hot-air oven at $100^{\circ} \mathrm{C}$ for estimation of in vitro DM digestibility (IVDMD). This is the difference between the weights of DM incubated and $\mathrm{DM}$ of the residue left behind. In vitro true organic matter digestibility (IVOMD) was estimated by ashing the residue at $550^{\circ} \mathrm{C}$ for $2 \mathrm{~h}$. The net gas production along with in vitro total DM digestibility (IVTDMD) and in vitro total organic matter digestibility (IVTOMD) was used for the calculation of partitioning factor $(\mathrm{PF})$ and microbial biomass production (MBP) $)^{12}$.

\section{Chemical analyses}

Standard methods of AOAC were followed for determining DM, $\mathrm{CP}(\mathrm{N} \times 6.25)$, EE and total $\mathrm{ash}^{13}$. Fibre fractions like neutral detergent fibre (NDF) and acid detergent fibre (ADF) were assayed according to Van Soest et al. ${ }^{14}$ $\mathrm{NH}_{3}-\mathrm{N}$ was estimated from supernatant samples using Kjeldahl method. For VFA analysis $0.8 \mathrm{ml}$ of the supernatant sample mixed with $0.2 \mathrm{ml}$ of metaphosphoric acid solution $(250 \mathrm{~g} / \mathrm{l})$ was injected into the gas chromatograph (fitted with FID and stainless steel column packed with Chromosorb-101), following the protocol described by Erwin et al. ${ }^{15}$. All the analyses were done in triplicate.

\section{Statistical analysis}

The data were analysed by one-way analysis of variance using SAS software ${ }^{16}$. Means were separated for statistical significance at $1 \%$ level $(P \leq 0.01)$ using post-hoc comparison by Tukey's Studentized Range Test.

\section{Results and discussion}

\section{Chemical composition of samples and total mixed rations}

Table 1 presents the chemical composition of feed samples and TMRs used for the in vitro study. NS and SS contained approximately similar levels of organic matter (OM), EE and CP. However, NDF content (DM basis) of NS $(254 \mathrm{~g} / \mathrm{kg})$ was slightly lower than that of SS $(285 \mathrm{~g} / \mathrm{kg})$, whereas ADF content of NS $(212 \mathrm{~g} / \mathrm{kg})$ was slightly higher than that of SS $(191 \mathrm{~g} / \mathrm{kg})$.

All presented values for samples are within the normal range as reported in the literature ${ }^{8,10}$. Incorporation of sunflower and niger seeds at various levels changed the chemical composition of the treatment TMRs in comparison to TMRc (negative control). However, TMRs containing similar incremental levels of niger and sunflower seeds possessed almost similar chemical composition.

\section{Effect on in vitro gas production and methane emission}

As shown in Table 2, all NS- and SS-based rations decreased $(P \leq 0.01)$ net gas production $\left(\mathrm{GV}_{24 \mathrm{~h}}\right)$ and $\mathrm{CH}_{4}$ emission almost in a linear fashion in comparison to control. Reduced rate of $\mathrm{GV}_{24 \mathrm{~h}}$ by treatments compared to the control indicates diminished ruminal degradability. Relatively comparable $\mathrm{GV}_{24 \mathrm{~h}}$ up to $5 \%$ incorporation level of 
RESEARCH ARTICLES

Table 1. Chemical composition ( $\mathrm{g} / \mathrm{kg}^{-1}$ dry matter (DM)) of samples and total mixed rations containing graded levels of niger and sunflower seeds

\begin{tabular}{|c|c|c|c|c|c|c|c|c|c|c|c|}
\hline Ingredient & SS & NS & TMRc & TMRs-3 & TMRs-5 & TMRs-7 & TMRs-9 & TMRn-3 & TMRn-5 & TMRn-7 & TMRn-9 \\
\hline Organic matter & 965 & 948 & 896 & 901 & 898 & 901 & 900 & 898 & 899 & 898 & 897 \\
\hline Crude protein & 198 & 212 & 131 & 133 & 134 & 136 & 137 & 133 & 134 & 136 & 137 \\
\hline Ether extract & 402 & 395 & 27 & 38 & 45 & 51 & 58 & 38 & 45 & 51 & 57 \\
\hline Neutral detergent fibre & 285 & 254 & 485 & 492 & 497 & 508 & 517 & 491 & 496 & 503 & 513 \\
\hline Acid detergent fibre & 191 & 212 & 300 & 301 & 303 & 305 & 308 & 302 & 304 & 307 & 310 \\
\hline $\mathrm{ASH}$ & 35 & 52 & 104 & 99 & 102 & 99 & 100 & 102 & 101 & 102 & 103 \\
\hline
\end{tabular}

SS, Sunflower seeds; NS, Niger seed; TMRc, Control total mixed rations; TMRs $(3,5,7,9)$, TMR containing SS at 3\%, 5\%, 7\% and 9\% respectively; TMRn $(3,5,7,9)$, TMR containing NS at $3 \%, 5 \%, 7 \%$ and $9 \%$ respectively.

Table 2. In vitro gas production and associated parameters of total mixed rations containing graded levels of sunflower and niger seeds

\begin{tabular}{|c|c|c|c|c|c|c|c|c|c|c|}
\hline Parameter & $\mathrm{TMR}_{\mathrm{C}}$ & TMRs-3 & TMRs-5 & TMRs-7 & TMRs-9 & TMRn-3 & TMRn-5 & TMRn-7 & TMRs-9 & SEM \\
\hline $\begin{array}{l}\text { Total gas, } \\
\mathrm{GV}_{24 \mathrm{~h}}(\mathrm{ml} / \mathrm{g})\end{array}$ & $208.75^{d}$ & $198.33^{c}$ & $195.83^{\mathrm{abc}}$ & $193.45^{\mathrm{abc}}$ & $190.66^{\mathrm{ab}}$ & $196.25^{\mathrm{bc}}$ & $195.00^{\mathrm{abc}}$ & $192.91^{\mathrm{abc}}$ & $189.50^{\mathrm{a}}$ & 0.66 \\
\hline Methane (\%) & $32.07^{\mathrm{e}}$ & $27.79^{d}$ & $26.94^{\mathrm{cd}}$ & $25.86^{\mathrm{bc}}$ & $25.12^{\mathrm{ab}}$ & $27.02^{\mathrm{cd}}$ & $26.58^{\mathrm{cd}}$ & $25.81^{\mathrm{bc}}$ & $24.14^{\mathrm{a}}$ & 0.23 \\
\hline Methane $(\mathrm{ml} / \mathrm{g})$ & $66.63^{\mathrm{e}}$ & $54.88^{\mathrm{d}}$ & $52.55^{\mathrm{cd}}$ & $49.81^{\mathrm{bc}}$ & $47.70^{\mathrm{ab}}$ & $52.79^{\mathrm{cd}}$ & $51.58^{\mathrm{cd}}$ & $49.51^{\mathrm{bc}}$ & $45.52^{\mathrm{a}}$ & 0.61 \\
\hline IVDMD (\%) & $67.46^{\mathrm{c}}$ & $66.43^{c}$ & $65.96^{\mathrm{c}}$ & $63.58^{\mathrm{b}}$ & $62.80^{\mathrm{ab}}$ & $66.20^{\mathrm{c}}$ & $65.95^{\mathrm{c}}$ & $63.11^{\mathrm{ab}}$ & $61.59^{\mathrm{a}}$ & 0.22 \\
\hline IVOMD (\%) & $67.18^{\mathrm{c}}$ & $67.031^{\mathrm{c}}$ & $66.22^{\mathrm{c}}$ & $64.56^{\mathrm{ab}}$ & $63.19^{\mathrm{a}}$ & $66.69^{c}$ & $66.15^{\mathrm{c}}$ & $64.35^{\mathrm{ab}}$ & $63.09^{\mathrm{a}}$ & 0.17 \\
\hline $\mathrm{PF}$ & $3.22^{\mathrm{a}}$ & $3.41^{\mathrm{b}}$ & $3.39^{\mathrm{b}}$ & $3.33^{\mathrm{ab}}$ & $3.29^{\mathrm{ab}}$ & $3.37^{\mathrm{b}}$ & $3.36^{\mathrm{b}}$ & $3.32^{\mathrm{ab}}$ & $3.30^{\mathrm{ab}}$ & 0.01 \\
\hline MBP (mg) & $254.30^{\mathrm{ab}}$ & $277.86^{\mathrm{d}}$ & $272.28^{\mathrm{cd}}$ & $252.91^{\mathrm{a}}$ & $249.84^{\mathrm{a}}$ & $270.23^{\mathrm{bcd}}$ & $269.88^{\text {bcd }}$ & $256.62^{\mathrm{abc}}$ & $249.57^{\mathrm{a}}$ & 1.48 \\
\hline
\end{tabular}

IVDMD, In vitro dry matter digestibility; IVOMD, In vitro true organic matter digestibility; PF, Partitioning factor; MPB, Microbial biomass production. ${ }^{\mathrm{a}-\mathrm{e}}$ Means in the same row with different superscripts $\operatorname{differ}(P<0.01)$.

the seeds implies that beyond this inclusion level, carbohydrate fermentability may get hampered. Our results are in agreement with previous reports ${ }^{17,18}$, where lower rates of GP have been reported. However, they contradict earlier reports where sunflower oil supplementation to forage-based diets did not affect total gas and $\mathrm{CH}_{4}$ production $^{19}$.

Lower $\mathrm{CH}_{4}$ production (ml/g DM) for treatment rations may be attributed to the anti-methanogenic property of PUFA of niger and sunflower seeds. Niger and Sunflower seeds are rich sources of PUFA which are toxic to methanogens and thus inhibit methanogenesis ${ }^{20,21}$. In the present study, niger seeds were comparatively more effective for $\mathrm{CH}_{4}$ abatement than sunflower seeds. Reduction in $\mathrm{CH}_{4}$ production was also expected because increased level of oilseeds in the rations was accompanied by increased propionate, which incorporates reducing equivalents necessary for $\mathrm{CH}_{4}$ production ${ }^{22}$. Reduced $\mathrm{DM}$ and $\mathrm{OM}$ digestibility at $7 \%$ and $9 \%$ inclusion levels of both the seeds might have augmented the suppression of $\mathrm{CH}_{4}$ production to more significant levels. The result contradicts earlier reports where sunflower oil supplementation to forage-based diets did not affect $\mathrm{CH}_{4}$ production ${ }^{19}$. However, the results are consistent with other findings ${ }^{3,23}$.

\section{Effect on in vitro DM and OM digestibility}

IVDMD and IVOMD were comparable with control up to $5 \%$ incorporation level of both seeds and decreased $(P \leq 0.01)$ thereafter. Thus, our finding indicates that inclusion of NS and SS in TMR at 5\% (DM-basis) would be optimal for ruminal ecosystem, microbial activity and thus nutrient digestibility. Significant reduction in in vitro digestibility may be attributed to anti-microbial activity of PUFA ${ }^{21,24}$, and thus slower rate of substrate degradation at higher incorporation levels. This indicates that degradation rate may also affect ruminal fermentation of unsaturated fat sources like niger and sunflower seeds. Partitioning factor (PF), which is the measure of efficiency of microbial protein synthesis in vitro ${ }^{25}$, remained within the normal range (2.74-4.41). Higher values of PF for TMRs-3, TMRs-5, TMRn-3 and TMRn-5 imply better utilization of the oilseed proteins by rumen microbes at $3 \%$ and $5 \%$ inclusion levels of both niger and sunflower seeds. This may be attributed to higher OM digestibility at these levels.

\section{Effect on in vitro rumen fermentation}

Table 3 presents the in vitro fermentation pattern of treatment rations. The $\mathrm{pH}$ values for all treatments were within the range (5.4 and 6.7) acceptable for optimal rumen fermentation. Lack of effect on $\mathrm{pH}$ may be due the inability of these seeds to elicit any effect on the concentration of total volatile fatty acids (tVFA). Our results are in agreement with those of Beauchemin et al. ${ }^{26}$ who reported that feeding sunflower seeds does not affect the rumen $\mathrm{pH}$ or tVFA concentration.

$\mathrm{NH}_{3}-\mathrm{N}$ concentration decreased $(P \leq 0.01)$ linearly in response to the graded levels of NS and SS compared to control (Table 3). Reduction in $\mathrm{NH}_{3}-\mathrm{N}$ with the addition 
RESEARCH ARTICLES

Table 3. In vitro rumen fermentation pattern of total mixed rations containing graded levels of sunflower and niger seeds

\begin{tabular}{|c|c|c|c|c|c|c|c|c|c|c|}
\hline Parameter & $\mathrm{TMR}_{\mathrm{C}}$ & TMRs-3 & TMRs-5 & TMRs-7 & TMRs-9 & TMRn-3 & TMRn-5 & TMRn-7 & TMRn-9 & SEM \\
\hline $\mathrm{pH}$ & 6.62 & 6.58 & 6.55 & 6.52 & 6.49 & 6.60 & 6.58 & 6.59 & 6.50 & 0.01 \\
\hline $\mathrm{NH}_{3}-\mathrm{N}(\mathrm{mg} / \mathrm{dl})$ & $16.75^{\mathrm{c}}$ & $16.52^{\mathrm{bc}}$ & $16.21^{\mathrm{a}}$ & $16.14^{\mathrm{b}}$ & $15.70^{\mathrm{a}}$ & $16.14^{\mathrm{ab}}$ & $16.03^{\mathrm{b}}$ & $15.62^{\mathrm{a}}$ & $15.71^{\mathrm{b}}$ & 0.05 \\
\hline $\operatorname{tVFA}(\mathrm{mM} / \mathrm{l})$ & 92.87 & 92.43 & 93.12 & 93.26 & 93.48 & 92.51 & 92.97 & 93.13 & 93.24 & 0.12 \\
\hline Acetate $(\mathrm{mM} / 1)$ & $59.39^{\mathrm{a}}$ & $59.17^{\mathrm{a}}$ & $59.36^{\mathrm{a}}$ & $59.52^{\mathrm{a}}$ & $60.01^{\mathrm{ab}}$ & $59.14^{\mathrm{a}}$ & $59.84^{\mathrm{a}}$ & $59.53^{\mathrm{a}}$ & $60.02^{\mathrm{ab}}$ & 0.09 \\
\hline Propionate $(\mathrm{mM} / \mathrm{l})$ & $19.45^{\mathrm{a}}$ & $19.77^{\mathrm{a}}$ & $20.36^{\mathrm{b}}$ & $20.57^{\mathrm{b}}$ & $21.92^{\mathrm{c}}$ & $19.85^{\mathrm{a}}$ & $20.55^{\mathrm{a}}$ & $20.67^{\mathrm{b}}$ & $20.95^{\mathrm{c}}$ & 0.07 \\
\hline Butyrate $(\mathrm{mM} / \mathrm{l})$ & 9.62 & 9.14 & 9.36 & 9.43 & 8.66 & 9.22 & 9.13 & 8.87 & 8.73 & 0.06 \\
\hline Acetate : propionate ratio & 3.05 & 2.99 & 2.91 & 2.89 & 2.84 & 2.98 & 2.91 & 2.88 & 2.86 & 0.02 \\
\hline Isobutyrate $(\mathrm{mM} / 1)$ & 4.11 & 4.06 & 3.98 & 4.15 & 3.84 & 3.91 & 3.79 & 4.12 & 3.87 & 0.06 \\
\hline Isovalerate $(\mathrm{mM} / \mathrm{l})$ & 4.39 & 4.18 & 3.96 & 4.01 & 4.03 & 4.06 & 4.08 & 4.11 & 4.15 & 0.05 \\
\hline Valerate $(\mathrm{mM} / \mathrm{l})$ & 2.37 & 2.41 & 2.01 & 1.90 & 2.05 & 2.20 & 1.98 & 2.16 & 2.04 & 0.05 \\
\hline
\end{tabular}

${ }^{\mathrm{a}-\mathrm{c}}$ Means in the same row with different superscripts differ $(P<0.01)$. tVFA, Total volatile fatty acids.

of sunflower and niger seeds indicates the antimicrobial activity of these seeds on ruminal microbiota. Reduced levels of $\mathrm{NH}_{3}-\mathrm{N}$ might have occurred due to suppression of the population and activity of ruminal protozoa ${ }^{27}$ which are the key players for ruminal protein degrada$\operatorname{tion}^{28}$, or reduced peptidolytic activity of ruminal bacteria $^{29}$. The decreasing trend observed in the concentration of ammonia- $\mathrm{N}$ is consistent with previous findings ${ }^{30,31}$.

Incorporation of NS and SS at various incremental levels did not alter tVFA concentration in contrast to TMRs. However, the molar proportion of acetate increased at $9 \%$ inclusion levels, whereas propionate concentration showed a linearly increasing $(P \leq 0.01)$ trend with the incorporation of treatments. Furthermore, treatments did not affect the molar proportions of butyrate, isobutyrate, isovalerate and valerate. Increased acetate concentration at $9 \%$ inclusion level may be probably related to high fibre content of these rations; whereas the observed increase in propionate is justified by the reduction in methane production, as the generation of propionate incorporates reducing equivalents ${ }^{22}$. Increased molar proportion of propionate in this study is in line with earlier findings ${ }^{32}$. Despite the increase in propionate, no change was observed in acetate propionate ratio. Our results are inconsistent with those of other researchers, who did not observe any effect on the molar proportions of VFA upon sunflower seed supplementation ${ }^{33,34}$. Increased molar concentration of propionate indicates that NS- and SSbased TMRs may have a positive consequence on the productive performance of animals.

\section{Conclusion}

Fermentation pattern of niger seeds was highly comparable to sunflower seeds. NS depicted higher potential of reducing $\mathrm{CH}_{4}$ relative to $\mathrm{SS}$. Reduction in in vitro digestibility at higher levels may limit the inclusion level of the seeds to $5 \%$. However, the outcome of this study needs an in vivo validation in various classes of ruminants.
Conflict of interest: The authors declare no conflict of interest.

1. Knapp, J. R., Laur, G. L., Vada, P. A, Weiss, W. P. and Tricarico, J. M., Invited review: enteric methane in dairy cattle production: quantifying the opportunities and impact of reducing emissions. J. Dairy Sci., 2014, 97, 3231-3261.

2. Patra, A. K. and Saxena, J. A., New perspective on the use of plant secondary metabolites to inhibit methanogenesis in the rumen. Photochemistry, 2010, 71, 1198-1222.

3. Beauchemin, K. A., McGinn, S. M. and Petit, H. V., Methane abatement strategies for cattle: lipid supplementation of diets. Can. J. Anim Sci., 2007, 87, 431-440.

4. Calsamiglia, S., Busquet, M., Cardozo, P. W., Castillejos, L. and Ferret, A., Invited review: essential oils as modifiers of rumen microbial fermentation. J. Dairy Sci., 2007, 90, 2580-2595.

5. Newbold, C. J., de la Fuente, G., Belanche, A., Ramos-Morales, E. and McEwan, N. R., The role of ciliate protozoa in the rumen. Front Microbiol., 2015, 6, 1313.

6. Guyader, J., Eugene, M., Noziere, P., Morgavi, D. P., Doreau, M. and Martin, C., Influence of rumen protozoa on methane emission in ruminants: a meta-analysis approach. Animal, 2014, 8, 18161825 .

7. Ramadan, M. F. and Moersel, J. T., Proximate neutral lipid composition of niger (Guizotia abyssinica Cass.) seed. Czech. J. Food Sci., 2002, 20, 98-104.

8. National Research Council, Nutrient Requirements of Dairy Cattle, National Academy of Sciences, Washington DC, 2001, 7th revised edn.

9. Prieto-Manrique, E., Mahecha-Ledesma, L., Vargas-Sánchez, J. E. and Angulo-Arizala, J., The effect of sunflower seed oil supplementation on the milk fatty acid contents of cows fed leucaena in an intensive silvopastoral system. Anim. Feed Sci. Technol., 2018, 239, 55-65.

10. ICAR, Nutrient Requirements of Cattle and Buffalo, Indian Council of Agricultural Research, New Delhi, 2013.

11. Menke, K. H. and Steingass, H., Estimation of the energetic feed value obtained from chemical analysis and in vitro gas production using rumen fluid. Anim. Res. Develop., 1988, 28, 7-55.

12. Blummel, M., Givens, D. I. and Moss, A. R., Comparison of methane produced by straw fed sheep in open circuit respiration with methane predicted by fermentation characteristics measured by an in vitro gas procedure. Anim. Feed Sci. Technol., 2005, 123, 379-390.

13. AOAC, Official Methods of Analysis, Association of Official Analytical Chemists, MD, USA, 2005, 18th revised edn.

14. Van Soest, P. J., Robertson, J. B. and Lewis, B. A., Methods for dietary fiber, neutral detergent fiber, and nonstarch 
polysaccharides in relation to animal nutrition. J. Dairy Sci., 1991, 74, 3583-3597.

15. Erwin, E. S., Macro, G. A. and Emery, E. M., Volatile fatty acid analysis of blood and rumen fluid by gas chromatograph. J. Dairy Sci., 1961, 44, 1768-1771.

16. SAS, User's Guide: Statistics, SAS Institute Inc, NC, USA, 2002.

17. Kholif, A. E., Elghandour, M. M. Y., Salem, A. Z. M., Barbabosa, A., Marquez, O. and Odongo, N. E., The effects of three total mixed rations with different concentrate to maize silage ratios and different levels of microalgae Chlorella vulgaris on in vitro total gas, methane and carbon dioxide production. J. Agric. Sci., 2017, 155, 494-507.

18. Vargas, J. E., Andrés, S., Yáñez Ruiz, D. R. and López, S., The effect of olive, sunflower or linseed oils on the fermentation pattern and methane production in the rumen simulating technique. Options Méditerr., 2011, 99, 163-168.

19. Narimani-Rad, M., Shahryar, H. A., Nahand, M. K. and Lotfi, A., Effect of sunflower oil supplementation on in vitro fermentation patterns of forage based diets for ruminant. Bull. Environ. Pharmacol. Life Sci., 2012, 1(12), 73-77.

20. Henderson, C., The effects of fatty acids on pure cultures of rumen bacteria. J. Agric. Sci., 1973, 81, 107-112.

21. Maia, M. R. et al., Toxicity of unsaturated fatty acids to the biohydrogenating ruminal bacterium, Butyrivibrio fibrisolvens. BMC Microbiol., 2010, 18, 10-52.

22. Gómez, J. A., Tejido, M. L. and Carro, M. D., Influence of disodium malate on microbial growth and fermentation in rumensimulation technique fermenters receiving medium- and highconcentrate diets. Br. J. Nutr., 2005, 93, 479-484.

23. McGinn, S. M., Beauchemin, K. A., Coates, T. and Colombatto, D., Methane emissions from beef cattle: effects of monensin, sunflower oil, enzymes, yeast, and furmaric acid. J. Anim. Sci., 2004, 82, 3346-3356.

24. Giger-Reverdins, Morand-Fehr, P. and Tran, G., Literature survey of the influence of dietary fat composition on methane production in dairy cattle. Livest. Prod. Sci., 2003, 82, 73-79.

25. Blummel, M., Makkar, H. P. S. and Becker, K., In vitro gas production: a technique revisited. J. Anim. Physiol. Anim. Nutr., 1997, 77, 24-34.

26. Beauchemin, K. A., McGinn, S. M., Benchaar S. C. and Holtshausen, L., Crushed sunflower, flax, or canola seeds in lactating dairy cow diets: effects on methane production, rumen fermentation, and milk production. J. Dairy Sci., 2009, 92, 2118-2127.
27. Bodas, R., Prieto, N., Garcia-Gonzalez, R., Andres, S., Giraldez, F. J. and Lopez, S., Manipulation of rumen fermentation and methane production with plant secondary metabolites. Anim. Feed Sci. Technol., 2012, 176, 78-93.

28. Jouany, J. P., Effect of rumen protozoa on nitrogen utilization by ruminants: altering ruminal nitrogen metabolism to improve protein utilization. J. Nutr., 1996, 126, 1335-1346.

29. Busquet, M., Calsamiglia, S., Ferret, A., Cardozo, P. and Kamel, C., Effects of innamaldehyde and garlic oil on rumen microbial fermentation in a dual flow continuous culture. J. Dairy Sci., 2005, 88, 2508-2516.

30. Gomaa, A. S., Kholif, A. E., Kholif, A. M., Salama, R., El-Alamy, H. A. and Olafadehan, O. A., Sunflower oil and nannochloropsis oculata microalgae as sources of unsaturated fatty acids for mitigation of methane production and enhancing diets' nutritive value. J. Agric. Food Chem., 2018, 66, 1751-1759.

31. Morsy, T. A., Kholif, S. M., Kholif, A. E., Matloup, O. H., Salem, A. Z. M. and Elella, A. A., Influence of sunflower whole seeds or oil on ruminal fermentation, milk production, composition, and fatty acid profile in lactating goats. Asian Australas J. Anim. Sci., 2015, 28(8), 1116-1122.

32. Sarrazin, P., Mustafa, A. F., Chouinard, P. Y., Raghavan, G. S., and Sotocinal, S. A., Performance of dairy cows fed roasted sunflower seed. J. Sci. Food Agric., 2004, 84, 1179-1185.

33. Finn, A. M., Clark, A. K., Drackley, J. M., Schingoethe, D. J. and Sahlu, T., Whole rolled sunflower seeds with or without additional limestone in lactating dairy cattle rations. J. Dairy Sci., 1985, 68, 903-913.

34. Casper, D. P., Schingoethe, D. J., Middaugh, R. P. and Baer, R. J., Lactational responses of dairy cows to diets containing regular and high oleic acid sunflower seeds. J. Dairy Sci., 1988, 71, 12671274.

ACKNOWLEDGEMENTS. We thank the Ministry of Environment and Forests, Government of India and ICAR-NDRI, Karnal for providing funds and the necessary research facilities respectively. T.A.M. thanks Indian Council of Agricultural Research, New Delhi for the award of research fellowship.

Received 27 December 2018; revised accepted 17 October 2020

doi: $10.18520 /$ cs/v120/i3/509-513 